\title{
Pentingnya Kolaborasi dalam Menciptakan Sistem Pendidikan yang Berkualitas
}

\author{
Zulmi Ramdani ${ }^{(1)}$, Silmi Amrullah ${ }^{(2)}$, Lidwina Felisima Tae ${ }^{(3)}$ \\ zulmiramdani94@gmail.com \\ ${ }^{(1)}$ Fakultas Psikologi, Universitas Islam Negeri Sunan Gunung Djati, Bandung, Indonesia \\ ${ }^{(2)}$ Fakultas Pendidikan, Universitas Pendidikan Indonesia, Bandung, Indonesia \\ ${ }^{(3)}$ Fakultas Pendidikan, University College London (UCL), London, United Kingdom
}

\begin{abstract}
A good education system is created when the school is led by a competent and creative principal, as well as those who are able to foster good relationships with teachers at the school. In addition, teachers with appropriate personalities and competencies will support the creation of a good learning environment and encourage their students to actively perform and make them personal. This study aims to provide clear information about the importance of collaboration among elements of educational support. The study used a mixed case study methodology, an open questionnaire, and a descriptive statistical analysis of 173 subjects consisting of two principals, 43 teachers, and 130 students. The results of case studies explain how the role of principals is crucial in shaping the character and performance of schools, especially with regard to their leadership style and creativity. While the analysis of open questionnaires categorizes that students expect to become dream teachers are those who are able to become partners, those who have the competence, and those who are experienced. The role of the principal, the presence of a qualified teacher, and the similarity of students' perceptions to their school will result in a collaboration that is mutually supportive of one another.
\end{abstract}

Keywords: good teacher; good quality of education; collaboration; principal's role

Sistem pendidikan yang baik tercipta ketika sekolah dipimpin oleh kepala sekolah yang kompeten dan kreatif, juga mereka yang mampu membina hubungan yang baik dengan guruguru di sekolah tersebut. Selain itu guru-guru dengan kepribadian dan kompetensi yang sesuai akan mendukung terciptanya suasana belajar yang baik dan mendorong siswanya untuk aktif berprestasi dan menjadikan mereka pribadi yang baik. Penelitian ini bertujuan untuk memberikan informasi yang jelas mengenai pentingnya kolaborasi di antara elemenelemen penunjang pendidikan tersebut. Studi ini menggunakan metodologi campuran studi kasus, kuesioner terbuka, dan analisis statistik deskriptif terhadap 173 subjek yang terdiri dari dua orang kepala sekolah, 43 orang guru, dan 130 orang siswa. Hasil dari studi kasus menjelaskan tentang bagaimana peran kepala sekolah sangat penting dalam membentuk karakter dan performa sekolah, terutama berkaitan dengan gaya kepemimpinan dan kreativitas mereka. Sedangkan analisis terhadap kuesioner terbuka mengategorikan bahwa siswa mengharapkan untuk menjadi guru idaman adalah mereka yang mampu menjadi partner, mereka yang memunyai kompetensi, dan mereka yang berpengalaman. Peran kepala sekolah, keberadaan seorang guru yang mumpuni, dan kesamaan persepsi siswa dengan sekolah mereka akan menghasilkan satu kolaborasi yang saling mendukung satu dengan yang lainnya.

Kata kunci: guru yang baik; kolaborasi; pendidikan berkualitas; peran kepala sekolah

Received: September 20, 2018 Accepted: May 20, 2019

How to cite: Ramdani, Z., Amrullah, S., \& Tae, L. F. (2019). Pentingnya Kolaborasi dalam Menciptakan Sistem Pendidikan yang Berkualitas. MEDIAPSI, 5(1), 40-48. doi: https://doi.org/10.21776/ub.mps.2019.005.01.4

\section{Pendahuluan}

Keberhasilan dan kemajuan suatu negara salah satunya ditopang oleh sistem pendidikan yang baik sehingga menghasilkan sumber daya manusia yang kompeten dan berkepribadian unggul. Sesuai dengan amanah Undang- 
Undang Republik Indonesia nomor 23 tahun 2003, yang menyebutkan pendidikan sebagai usaha sadar dan terencana untuk mewujudkan suasana belajar dan proses pembelajaran agar peserta didik secara aktif mengembangkan potensi dirinya untuk memiliki kekuatan spiritual keagamaan, pengendalian diri, kepribadian, kecerdasan, akhlak mulia, serta keterampilan yang diperlukan dirinya, masyarakat, bangsa, dan negara (Departemen Agama RI, 2003). Mengacu kepada dasar dalam undang-undang tersebut sudah seharusnya kondisi pendidikan kita saat ini mengarah kepada kemakmuran secara menyeluruh.

Pada kenyataanya, kondisi pendidikan Indonesia saat ini masih dalam pertumbuhan yang belum stabil. Berdasarkan data yang disampaikan dalam Social Progress Index, Indonesia berada di posisi ke-38 dari 50 negara di dunia mengenai kemajuan suatu negara yang didalamnya terdapat indikator dalam memperoleh akses pendidikan yang tepat (Porter, Stren, \& Loria, 2013). Selain itu, data dari Global Competitiveness Report juga memposisikan Indonesia pada situasi yang sama terutama dalam aspek primary education dan higher education yang berada dibawah beberapa negara ASEAN seperti Singapura, Malaysia, dan Thailand (Schwab, 2017). Informasi demikian menjadikan situasi pendidikan Indonesia memperlukan perhatian yang lebih besar terutama di dalam membangun sumber daya manusia yang berkualitas.

Permasalahan yang terjadi saat ini salah satunya dikarenakan faktor sumber daya manusia yang secara mendasar adalah aktor yang akan menggerakan pendidikan. Pertama sekolah tidak mempunyai sosok pemimpin yang mempunyai kekuatan dan energi positif dalam membangun iklim dan budaya belajar yang baik. Kedua, sekolah kehilangan karakter-karakter guru yang secara praktis bukan hanya berfokus pada aspek pengajaran kognitif melainkan seluruh aspek sikap, perilaku, moral, dan juga kognitif. Dan yang ketiga mudah terjadinya perbedaan persepsi diatara siswa dengan lingkungannya sehingga memunculkan demotivasi yang mengalahkan prestasi.

Kesuksesan dalam pendidikan adalah hasil dari kolaborasi dari elemen-elemen dalam sistem pendidikan yang saling mendukung satu dengan yang lainnya (Sahlberg, 2010). Berkaca kepada negara seperti Finlandia yang selalu menjadi model yang tepat, salah satunya dikarenakan pada keseimbangan intervensi pada semua level pendidikan, dimana guru dan sekolah saling bekerja sama untuk menjadikan pembelajaran siswa pada posisi yang penting sehingga berfokus pada performa siswa dan menghilangkan kesenjangan dan perbedaan di antara sekolah (Sahlberg, 2010). Selain itu juga, peningkatan dari perilaku berinovasi dan tanggungjawab di antara elemen pendidikan akan menghadirkan mutu pendidikan yang lebih baik (Sahlberg, 2011). Beberapa hal yang menjadikan sebuah sistem pendidikan dianggap berhasil adalah adanya standardisasi dalam proses belajar maupun mengajar, memfokuskan pada proses dibandingkan hasil, kolaborasi antara kebijakan pemerintah dan kehadiran profesional, serta memunculkan beragam visi pendidikan terutama dalam memberikan kesempatan anak untuk selalu belajar, kreativitas, dan kemanusiaan (Sahlberg, 2011).

$$
\text { Informasi yang disampaikan }
$$
sebelumnya menegaskan bahwa untuk menciptakan kondisi pendidikan yang baik itu 
dibutuhkan seperangkat komponen yang saling mendukung satu dengan yang lainnya. Elemen-elemen tersebut meliputi keberadaan seorang kepala sekolah, keberadaan guru beserta kepribadiannya, dan juga peserta didik (Scheerens \& Blomeke, 2016). Hal mendasar yang harus dipahami oleh elemen-elemen tersebut adalah bahwa mereka merupakan subjek positif yang mempunyai seperangkat karakteristik-karakteristik positif yang diharapkan mampu menimbulkan kenyamanan dan kesejahteraan psikologis terutama dalam sebuah proses pembelajaran (Ramdani \& Fahmi, 2016).

Seorang kepala sekolah yang mempunyai keyakinan dan optmisme yang tinggi tentang keberhasilan akan membawa dia pada perspektif yang progres tentang bagaimana memajukan organisasi yang dipimpinnya (Hallinger \& Heck, 1996). Salah satunya adalah mengenai reformasi dalam mengantarkan visi sekolah tersebut (Hallinger, 1992). Peran kepala sekolah yang tepat akan menghasilkan kegiatan dan proses pembelajaran yang bermanfaat, keputusan yang adil, kordinasi yang baik, serta hubungan harmonis dengan guru dan siswa (Bossert, Dwyer, Rowan, \& Lee, 1982). Selain itu peran seorang guru juga ikut berkontribusi terhadap keberhasilan pendidikan. Saat ini guru banyak yang menitikberatkan pada kemampuan personal menjadi guru dibanding profesional yang lebih diunggulkan (Hosgorur, 2012). Siswa juga menginginkan guru adalah seorang mentor dan fasilitator yang memberikan dukungan dan pengajaran yang baik (Harden \& Crosby, 2009). Sehingga menjadi sosok seorang guru yang baik tidaklah mudah dikarenakan harus bersinergi dengan kepala sekolah, menunjukan perilaku dan kompetensi yang sesuai dengan misi yang diemban (Korthagen, 2004).
Kolaborasi yang tepat di antara kepala sekolah dan guru akan menghasilkan perspektif yang sama dalam mencapai visi yang ada di sekolah. Selain itu, keduanya harus mampu menjadi model baik bagi siswa, karena siswa cenderung lebih memilih apa yang ditampilkan oleh guru dan kepala sekolah mereka dibanding teman mereka sendiri (Brodaty \& Gurgand, 2016). Penekanan pada aspek personal dan kepribadian juga akan berpengaruh terhadap proses kolaborasi ini (Raufelder dkk., 2016). Studi ini bertujuan untuk memberikan informasi mengenai pentingnya kolaborasi di antara elemenelemen dalam pendidikan yang telah dijelaskan sebelumnya.

\section{Metode}

\section{Desain penelitian dan partisipan}

Penelitian ini dilakukan dengan menggunakan metodologi campuran kualitatif dan kuantitatif. Tahapan pertama, peneliti melakukan studi kasus dengan menggunakan purposive sampling terhadap dua orang kepala sekolah yang berada di Kepulauan Nias Barat (Eisenhardt, 1989). Tahapan kedua peneliti melakukan kuesioner terbuka dan melakukan pengodean mengenai karakteristikkarakteristik menjadi seorang guru idaman yang diperoleh dari analisis terhadap 130 kuesioner terbuka siswa (Ramdani, 2017). Tahapan ketiga, peneliti melakukan analisis deskriptif terhadap kategori karakter-karakter positif yang dibutuhkan oleh seorang guru dengan menggunakan kuesioner kekuatan karakter yang dikembangkan oleh Peterson dan Seligman (Ramdani \& Fahmi, 2016). Hasil dari ketiga proses tersebut akan menghasilkan deskripsi mengenai bagaimana peran masingmasing elemen itu muncul dan bagaimana saling berkolaborasi. 


\section{Hasil}

\section{Hasil analisis subjek (kepala sekolah) 1}

Berdasarkan hasil wawancara mendalam dengan subjek diperoleh beberapa temuan. Subjek adalah seorang laki-laki berusia 35 tahun kelahiran Nias Barat yang dengan semangat mudanya mampu membawa perubahan positif dalam menjadikan SMPN yang dipimpinnya berprestasi, mandiri, dan mempunyai citra yang baik bagi lingkungan masyarakat sekitar. Beberapa kategori yang muncul dari analisis di antaranya:

1. Menerapkan sistem yang berbasis pada keunggulan dan potensi anak. Potensi ini dikembangkan salah satunya melalui komunitas tari sekolah dengan menjadikan guru sekolah tersebut sebagai pelatihnya. Hasilnya sanggar tari ini terkenal dan sering menjadi tamu undangan dalam berbagai kegiatan yang ada di wilayah Kabupaten Nias Barat.

2. Menciptakan komunitas peduli sekolah, dimana kepala sekolah mengajak para guru untuk melakukan sosialiasai kepada masyarakat sekitar sekolah untuk saling bekerja sama membantu dan mendukung kegiatan sekolah. Kegiatan ini mampu mendatangkan minat warga untuk melakukan iuran rutin setiap minggu secara sukarela dalam membantu pertumbuhan sekolah baik fisik ataupun non material.

3. Ikut serta dalam acara gereja di sekitar sekolah yang kemudian kepala sekolah, guru, dan siswa mengambil kesempatan untuk melakukan lelang barang-barang yang sudah disiapkan dengan tujuan hasil akan digunakan membantu sekolah.

4. Kepala sekolah menitikberatkan bahwa hubungan dengan guru adalah sesuatu yang penting dan harus dibangun sejak awal, sehingga ketika ada kegiatan atau masalah tertentu semuanya bisa turut andil di dalamnya.

5. Karakter-karakter positif yang muncul dari kepala sekolah adalah kreativitas, perjuangan yang besar terhadap misi sekolah, keteguhan hati, dan kesabaran

\section{Hasil analisis subjek (kepala sekolah) 2}

Sama halnya dengan subjek pertama, pada subjek kedua ini kepala sekolah adalah seorang laki-laki berumur 42 tahun. Subjek termasuk orang yang dikenal dilingkungannya, karena setiap orang yang berpapasan dengannya tidak lupa untuk menyapa dan bersalaman sambil berdiskusi. Subjek juga adalah seorang kepala padukuan di wilayah Kepulauan Hinako, Nias Barat. Beberapa temuan dari kasus subjek kedua di antaranya:

1. Berperan ganda tidak hanya sebagai kepala sekolah, juga sebagai kepala bagian administrasi sekolah, kepala TU, dan menjadi guru di hampir semua mata pelajaran di sekolah. Hal ini mengasumsikan bahwa subjek berperan sangat aktif dan beragam dalam kasus ini.

2. Sosok subjek adalah seseorang yang mampu berbaur bersama dengan warga di mana hal ini menjadi karakter dan keunggulannya. Subjek beranggapan bahwa dirinya harus mampu menjadi partner terbaik sekolah bagi warga di daerahnya.

3. Kegiatan yang sering dilakukan setiap hari adalah menjadikan anak-anak di daerahnya tersebut mau bersekolah dan menanamkan nilai tentang kecintaan terhadap daerah dan juga memberikan motivasi terhadap pentingnya pendidikan.

4. Beberapa karakter yang muncul dari subjek 
adalah keteguhan hati, kesabaran, tanggungjawab, komitmen, dan sikap openminded terhadap orang luar. Subjek selalu menjelaskan kepada orang luar siapa saja yang datang ke wilayahnya untuk melihat potensi daerahnya.

5. Hal yang unik dari subjek adalah selalu menyampaikan motivasi dan pelajaran di kelas kepada siswa dengan menggunakan alat bantu gitar dengan keyakinan pendekatan yang baik dengan siswa dan guru akan membuat mereka mau untuk melakukan perubahan.

\section{Hasil analisis kuesioner terbuka}

Analisis terhadap hasil kuesioner terbuka dilakukan dengan cara melakukan koding terhadap unit-unit hasil yang relevan dengan topik atau masalah yang sedang diteliti. Ada dua kategori yang diperoleh dari hasil analisis terhadap jawaban terbuka siswa mengenai gambaran guru seperti apa yang mereka inginkan dan harapkan dapat menjadi sosok yang baik dalam proses pembelajaran.

Kategori pertama menghasilkan temuan mengenai bagaiamana sosok seorang guru yang diidamkan oleh siswa. Siswa menganggap bahwa setidaknya ada tiga hal yang mereka harapkan dari sosok seorang guru yang baik. hal-hal tersebut meliputi posisi guru sebagai partner siswa, guru mempunyai kompetensi dan kualitas yang sesuai, dan guru dianggap adalah seseorang yang mempunyai banyak pengalaman. Guru sebagai partner siswa digambarkan sebagai sosok yang bukan hanya menjadi pengajar semata bagi siswa, juga mereka yang mampu menjadi sahabat ketika siswa mempunyai masalah, mereka yang mampu menjadi orang tua mereka di kelas yang senantiasa memberikan nasihat dan motivasi positifnya, juga mereka yang senantiasa berkolaborasi dengan siswa dalam mencapai tujuan bersama. Guru adalah mereka yang mempunyai kompetensi dan kualitas sesuai yang dikemudian digambarkan dengan keahliannya dalam menyampaikan pelajaran, memberikan contoh ilmu yang tepat, mereka adalah orang yang cerdas, dan mereka mempunyai kemampuan problem solving yang baik. Sedangkan guru dianggap sebagai seseorang yang berpengalaman ketika mampu mengajarkan arti kehidupan, memberikan suri tauladan, mampu membangun karakter siswa, dan menanamkan nilai-nilai kebaikan.

Kategori yang kedua adalah mengenai karakter seorang guru yang diinginkan oleh siswa. Ada tiga hal penting yang diharapkan ada dalam karakter seorang guru yaitu karakter yang berkaitan dengan wisdom \& knowledge, karakter humanity \& love, serta karakter religious. Karakter yang pertama dideskripsikan sebagai sosok guru yang inovatif, kreatif, berawawasan luas, jiwa motivator, cerdas, komunikatif, open-minded, dan tekun. Karakter yang kedua berkaitan dengan humanity \& love digambarkan sebagai sosok yang ramah, tulus, penyayang, rendah hati, pendengar yang baik, cinta terhadap murid, suka memuji, murah senyum, peduli, simpati, dan empati yang tinggi. Sedangkan karakter yang ketiga sosok guru yang diharapkan adalah mereka yang sabar, ikhlas dalam mengajar muridnya, tawadhu dalam bekerja, amanah, dan jujur dalam berilmu. Penjelasan mengenai kategori sebelumnya bisa dilihat pada Tabel 1.

\section{Hasil analisis deskriptif}

Analisis deskriptif dilakukan dengan melihat hasil peroleh skala yang diberikan kepada 40 orang guru yang berisi tentang karakter-karakter yang dibutuhkan oleh guru dalam proses pembelajaran. Skala yang digunakan didasarkan pada kekuatan karakter 
yang dibuat oleh Peterson \& Seligman (2004) kemudian peneliti menggunakan skala yang dikembangkan oleh (Ramdani \& Fahmi, 2016).

Tabel 1

Kategori Guru Idaman

\begin{tabular}{ccl}
\hline No. & \multicolumn{1}{c}{ Kategori } & \multicolumn{1}{c}{ Indikator } \\
\hline 1. & Sosok Guru Idaman & Partner \\
\cline { 3 - 3 } & & Skills \\
\cline { 3 - 3 } & & Experienced \\
\hline $2 . \quad$ Karakter Guru Idaman & Wisdom \& Knowledge \\
\cline { 3 - 3 } & & Humanity \& Love \\
& & Religious \\
\hline
\end{tabular}

Gambar 1 menjelaskan mengenai bagaimana karakter guru yang menjadi subjek penelitian dalam studi ini. Dari enam karakter yang diujikan meliputi karakter love (cinta), kindness (kebaikan hati), emotional stability (keseimbangan emosional), creativity (kreativitas), open-minded (keterbukaan pikiran), dan love of learning (kecintaan belajar), hampir semua karakter di atas ratarata 50\%. Dengan demikian, melihat pada hasil analisis pada gambar diatas menjelaskan bahwa kesiapan guru dalam menciptakan pendidikan yang berkualitas sudah dibekali dengan karakteristik kepribadian yang mumpuni. Hanya saja pada bagian kreativitas mendapatkan skor terendah, yang artinya karakter ini belum sepenuhnya dikembangkan pada guru dalam subjek penelitian ini.

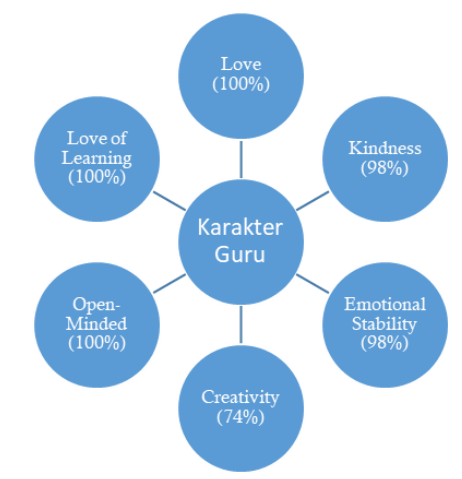

Gambar 1. Kesiapan Karakter Guru

\section{Diskusi}

Sebagaimana yang telah dipaparkan sebelumnya, bahwa sistem pendidikan yang baik haruslah dibangun melalui kerjasama yang konsisten di antara berbagai elemenelemen dalam sistem pendidikan nasional saat ini. Peran kepala sekolah mempunyai kontribusi paling besar karena sebagai dasar dan pintu utama terciptanya iklim dan budaya belajar yang baik. Sekolah yang dipimpin oleh seseorang yang kompeten di bidangnya, setidaknya akan menghasilkan kebijakan yang mampu dicapai oleh siswanya (Riehl, 2000). Dalam penelitian ini peran kepala sekolah lebih didasarkan atas kemampuan personal mereka dalam mengembangkan pendidikan yang unik sesuai cara mereka masing-masing. Seorang kepala sekolah yang secara sukarela mampu mencari alternatif dari setiap permasalahan dengan solusi yang baru dan memanfaatkan potensi yang ada dapat menjadi langkah awal dalam mengembangkan tipe kepemimpinan mereka di sekolah (Leithwood \& Montgomery, 1982). Berbeda dengan mereka yang hanya menjalankan apa yang sudah diamanahkan saja kepada mereka. Halhal penting yang menjadi kunci dari peran kepala sekolah ini adalah bagaimana seorang kepala sekolah dapat menciptakan suasana belajar yang efektif dan kordinasi yang harmonis dengan guru-guru yang lainnya. Selain itu mereka juga perlu menumbuhkan tipe kepempimpinan yang transformasional dibanding hanya manajerial ataupun instruksional.

Peran seorang kepala sekolah tidak akan berjalan sesuai keinginan jika tidak didukung oleh sumber daya guru yang mumpuni baik secara kompetensi ataupun secara personal. Guru sejatinya adalah alat utama dalam menciptakan generasi bangsa yang cerdas dan 
berkepribadian mulia (Murphy, Delli, \& Edwards, 2010). Guru yang diharapkan mampu membantu menciptakan pendidikan yang baik, akan memulai membentuk dirinya menjadi sosok yang hangat dan diidamkan oleh siswa mereka (Rooij \& Jansen, 2018). Guru yang baik akan menghasilkan siswa dengan performa yang baik pula. Hal itu akan menjadi pertimbangan bagi siapa saja yang ingin menjadi guru agar mempersiapkan diri dan kepribadian mereka sesuai dengan tuntutan lingkungan dan juga globalisasi (Berg, 2002). Hasil penelitian tentunya tidak serta merta mampu mendefinisikan sosok seorang guru yang sempurna. Tetapi dari hasil ini mampu menyajikan gambaran sederhana tentang bagaimana seharusnya dilakukan oleh seorang guru dengan berbagai keunikannya masing-masing.

Dalam studi sederhana ini dihasilkan bahwa karakter-karakter yang tepat dimiliki oleh seorang guru dalam menciptakan pendidikan yang baik sudah secara keseluruhan mereka miliki. Aspek-aspek yang meliputi kemampuan personal dan kemampuan yang berbasis kompetensi sudah dimiliki oleh mayoritas guru dalam subjek penelitian.

Titik kolaborasi dalam penelitian ini adalah bagaimana kepala sekolah sebagai elemen yang berada pada jalur kebijakan dan proses administrasi mampu menghasilkan situasi dan iklim sekolah yang mendukung proses belajar dan mengajar siswa. Selain itu itu juga kepala sekolah dan guru bersama-sama mempunyai tanggung jawab dan kesadaran penuh akan peran mereka masing-masing sehingga sejak awal mereka sudah mempersiapkan sikap dan perilaku mereka sesuai dengan apa yang diharapkan siswa. Dalam hal ini juga, siswa seharusnya mampu belajar dan mencoba menerima lingkungan mereka sebagai lingkungan yang positif, sehingga pada akhirnya akan terjadi kepedulian dan empati terhadap keberhasilan dalam proses pembelajaran. Hasil akhirnya adalah terjalin hubungan dan harmonisasi di antara elemen-elemen pendidikan.

Dengan demikian dapat dibuat simpulan bahwa berdasarkan penelitian ini kepala sekolah mempunyai peranan yang besar di dalam menciptakan iklim dan suasana belajar yang nyaman bagi siswa. Hal itu juga membuat hubungan antara kepala sekolah dan guru menjadi solid dan mampu menciptkan metode dan menghasilkan perspektif yang baik terhadap performa siswa-siswa mereka.

\section{Catatan dan Penghargaan}

Hasil studi ini diperoleh berdasarkan pengalaman penulis ketika sedang melakukan penelitian jangka panjang mengenai aspirasi sekolah di pedalaman Indonesia. Penulis ingin mengucapkan terima kasih banyak kepada Pusat Studi Kebijakan dan Kependudukan UGM yang telah bekerjsama dengan Kementrian Kebudayaan RI dan memilih penulis sebagai salah satu asisten lapangan di beberapa daerah di Sumatera Utara terutama masyarakat Pulau Samosir dan Kepulauan Nias.

\section{Daftar Pustaka}

Berg, R. van den. (2002). Teachers' meanings regarding educational practice. Review of Educational Research, 72(4), 557625.

https://doi.org/10.3102/0034654307200 4577

Bossert, S., Dwyer, D., Rowan, B., \& Lee, G. 
(1982). The instructional management role of the principal. Educational Administration Quarterly, 18(3), 34-64. doi:

\section{https://doi.org/10.1177/0013161X82018 $\underline{003004}$}

Brodaty, T., \& Gurgand, M. (2016). Good peers or good teachers? Evidence from a French university. Economic of Education Review, 54, 62-78. doi: http://dx.doi.org/10.1016/j.econedurev.2 $\underline{016.06 .005}$

Departemen Agama RI. (2003). UndangUndang Nomor 20 Tahun 2003 Tentang Sistem Pendidikan Nasional (hal. 1). Jakarta: Departemen Agama RI.

Eisenhardt, K. (1989). Building theories from case study research. Academy of Management Review, 14(4), 532-550. doi: http://dx.doi.org/10.2307/258557

Hallinger, P. (1992). The evolving role of American principals: From managerial to instructional to transformational leaders. Journal of Educational Administration, $\quad 30(3) . \quad$ doi: http://dx.doi.org/10.1108/09578239210 $\underline{014306}$

Hallinger, P., \& Heck, R. H. (1996). Reassessing the principal's role in school effectiveness: A review of empirical research, 1980-1995. Educational Administration Quarterly, 32(1), 5-44. doi:

https://doi.org/10.1177/0013161X96032 $\underline{001002}$

Harden, R. M., \& Crosby, J. (2009). AMEE Guide No 20: The good teacher is more than a lecturer -the twelve roles of the teacher. Medical Teacher, 22(4), 334347.

doi: https://doi.org/10.1080/0142159004094 $\underline{29}$

Hosgorur, T. (2012). A discussion of what makes a good teacher: Opinions of preservice primary school teacher. Procedia Social and Behavioral Sciences, 55, 451-460.

doi: https://doi.org/10.1016/j.sbspro.2012.09 .$\underline{524}$

Korthagen, F. A. J. (2004). In search of the essence of a good teacher: Toward a more holistic approach in teacher education. Teaching and Teacher Education, 20(1), 77-97. doi: https://doi.org/10.1016/j.tate.2003.10.00 $\underline{2}$

Leithwood, K. A., \& Montgomery, D. J. (1982). The role of the elementary school principal in program improvement. Review of Educational Research, 52(3), 309-339. https://doi.org/10.3102/0034654305200 $\underline{3309}$

Murphy, P. K., Delli, L. A. M., \& Edwards, M. N. (2010). The good teacher and good teaching: Comparing beliefs of secondgrade students, preservice teachers, and inservice teachers. The Journal of Experimental Education, 72(2), 69-92. doi:

https://doi.org/10.3200/JEXE.72.2.69$\underline{92}$

Porter, M. E., Stren, S., \& Loria, R. A. (2013). Social Progress Index 2013. Washington, DC: Social Progress Imperative.

Ramdani, Z. (2017). Forgiving is not only forgetting (phenomenological study on forgiveness in individu who experiences a friendship conflict. IJASOS- 
International E-Journal of Advances in Social Sciences, 3(9), 829-839. doi: https://doi.org/10.18769/ijasos.366853

Ramdani, Z., \& Fahmi, I. (2016). Profil kekuatan karakter dan kebajikan pada mahasiswa berprestasi. Psympathic: Jurnal Ilmiah Psikologi, 1(1), 98-108. doi:

https://doi.org/10.15575/psy.v1i1.471

Raufelder, D., Nitsche, L., Breitmeyer, S., Kebler, S., Herrmann, E., \& Regner, N. (2016). Student's perception of "good" and "bad" teacher: Results of qualitative thematic analysis with German adolesencents. International Journal of Education Research, 75, 31-44. doi: https://doi.org/10.1016/j.ijer.2015.11.00 $\underline{4}$

Riehl, C. J. (2000). The principal's role in creating inclusive schools for diverse students: A review of normative, empirical, and critical literature on the practice of educational administration. Review of Educational Research, 70(1), 55-81.

doi: https://doi.org/10.3102/0034654307000 $\underline{1055}$

Rooij, E. C. M., \& Jansen, E. P. W. A. (2018). "Our job is to deliver a good secondary school student, not a good university student." Secondary school teachers' beliefs and practices regarding university preparation. International Journal of Educational Research, 88, 919.

doi: https://doi.org/10.1016/j.ijer.2018.01.00 $\underline{5}$

Sahlberg P. (2010) Educational Change in Finland. Pada A. Hargreaves, A. Lieberman, M. Fullan, D. Hopkins (eds),
Second International Handbook of Educational Change. Springer International Handbooks of Education, vol 23. Dordrecht: Springer. doi: https://doi.org/10.1007/978-90-4812660-6_19

Sahlberg, P. (2011). The fourth way of Finland. Journal of Educational Change, 12(2), 173-185. doi: https://doi.org/10.1007/s10833-0119157-y

Scheerens, J., \& Blomeke, S. (2016). Integrating teacher education effectiveness research into educational effectiveness model. Educational Research Review, 18, 70-87. doi: http://dx.doi.org/10.1016/j.edurev.2016. 03.002

Schwab, K. (2017). The Global Competitiveness Report. Cologny: World Economic Forum. 